\title{
The incidence of malignant arrhythmia and death outcomes in patients with ischemic and nonischemic dilated cardiomyopathy with implantable cardioverter defibrillator - results of a single center
}

\author{
Mario Stipinovićn ${ }^{1 *}$, \\ Sofiya Andreykanich², \\ Darko Počanić', \\ Tomislav Letilović1,2, \\ Bojana Aćamović \\ Stipinović1, \\ Matija Marković1, \\ Ivica Premužić \\ Meštrović', \\ Helena Jerkić' \\ 'University Hospital Merkur, \\ Zagreb, Croatia, \\ ${ }^{2}$ University of Zagreb School \\ of Medicine, Zagreb, Croatia
}

RECEIVED:

August 28, 2017

ACCEPTED:

September 26, 2017

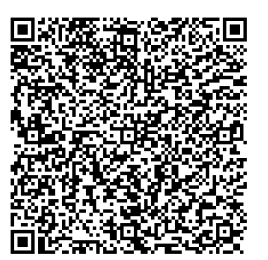

KEYWORDS: implantable cardioverter defibrillator, sudden cardiac death, dilated cardiomyopathy. CITATION: Cardiol Croat. 2017;12(9-10):379. | https://doi.org/10.15836/ccar2017.379

*ADDRESS FOR CORRESPONDENCE: Mario Stipinović, Klinička bolnica Merkur, Zajč eva 19, HR-10000 Zagreb, Croatia. / Phone: +385-98-1964-133 / E-mail: mario.stipinovic@yahoo.com

ORCID: Mario Stipinović http://orcid.org/0000-0002-1582-1552 • Sofiya Andreykanich http://orcid.org/0000-0002-9334-6371 Darko Počanić http://orcid.org/0000-0003-3257-110X • Tomislav Letilović http://orcid.org/0000-0003-1229-7983

Bojana Aćamović Stipinović http://orcid.org/0000-0003-4542-0028 • Matija Marković http://orcid.org/0000-0002-2852-3730 Ivica Premužić Meštrović http://orcid.org/0000-0002-2592-8302 • Helena Jerkić http://orcid.org/0000-0002-1650-4735 IIIIIIIIIIIIIIIIIIIIIIIIIIIIIIIIIIIIIIIIIIIIIIIIIIIIIIIIIIIIIIIIIIIIIIIIIIIIIIIIIIIIIIIIIIIIIIIIIIIIIIIIIIIIIIIII

Objectives: The indication for implantable cardioverter defibrillator (ICD) implantation is dilated cardiomyopathy (DCM), ischemic or nonischemic genesis, after three months of optimal medical therapy, with expected survival for more than one year ${ }^{1}$. Available data from two large randomized trials show there was no effect of ICD implantation in patients with nonischemic DCM in total mortality, but there was a significant reduction of sudden cardiac death $(S C D)^{2,3}$. The aim of this study was to analyze real data from our center.

Patients and Methods: During 2015 and 2016 we have implanted 35 ICDs in the primary prevention of SCD. The data were collected retrospectively and analyzed.

Results: We analyzed 33 patients (2 lost from follow up), 4 females (12.1\%) and 29 males (87.9\%). The average follow-up was 22.7 months. In 20 patients (57.1\%) the genesis of DCM was ischemic, and in 13 patients nonischemic (42.9\%). Analyzing both groups, in the ischemic group, 3 deaths were recorded $(15 \%)$, while in the nonischemic group 1 death was recorded $(7.7 \%)(p=0.48)$. All three deaths in ischemic group, as well as one in the nonischemic group, were the result of the terminal stage of cardiac insufficiency. Also, in the memory of the ICD in the ischemic group, malignant arrhythmias were recorded in 4 patients $(20 \%)$, while malignant arrhythmias $(\mathrm{p}=0.12)$ were not recorded in the nonischemic group. Conclusion: Comparing the obtained data from our center with data from large randomized trials we did not find benefit in total mortality in ischemic and nonischemic group ${ }^{2,3}$. In those trials there was significant reduction of SCD in nonischemic DCM due to successfully determination of malignant arrhythmias ${ }^{2,3}$, while our data suggested no benefit of ICD implantation in nonischemic group because there was no malignant arrhythmia in that group. Our data indicate a significant reduction in malignant arrhythmias in patients with nonischemic DCM. Because of the small number of patients, the results cannot be used for definitive conclusions without further investigation.

LITERATURE II!"

1. Priori SG, Blomström-Lundqvist C, Mazzanti A, Blom N, Borggrefe M, Camm J, et al. 2015 ESC Guidelines for the management of patients with ventricular arrhythmias and the prevention of sudden cardiac death: The Task Force for the Management of Patients with Ventricular Arrhythmias and the Prevention of Sudden Cardiac Death of the European Society of Cardiology (ESC). Endorsed by: Association for European Paediatric and Congenital Cardiology (AEPC). Eur Heart J. 2015 Nov 1;36(41):2793-867. https://doi.org/10.1093/eurheartj/ehv316

2. Kadish A, Dyer A, Daubert JP, Quigg R, Estes NA, Anderson KP, et al; Defibrillators in Non-Ischemic Cardiomyopathy Treatment Evaluation (DEFINITE) Investigators. Prophylactic defibrillator implantation in patients with nonischemic dilated cardiomyopathy. N Engl J Med. 2004 May 20:350(21):2151-8. https://doi.org/10.1056/NEJMoa033088

3. Køber L, Thune JJ, Nielsen JC, Haarbo J, Videbžk L, Korup E, et al; DANISH Investigators. Defibrillator Implantation in Patients with Nonischemic Systolic Heart Failure. N Engl J Med. 2016 Sep 29;375(13):1221-30. https://doi.org/10.1056/NEJMoa1608029 